\title{
PERENCANAAN KAWASAN UNTUK PENGEMBANGAN EKOWISATA PERAIRAN DI TELUK WEDA, MALUKU UTARA
}

\author{
Regional Planning For Water Ecotourism Development \\ at Weda Bay, North Molluccas
}

\section{Djamhur $\mathbf{M}^{1}$, Boer $\mathbf{M}^{2}$, Bengen DG, Fakhrudin A}

Diterima : 12 Desember 2013

Disetujui : 31 Januari 2014

\begin{abstract}
Abstrak: Teluk Weda merupakan kawasan teluk yang didalamnya terdapat sumberdaya terbaharui dan tidak terbaharui. Kondisi ini menjadikn dalam pengembangan Teluk Weda sebagai kawasan potensial, memerlukan zonasi dalam pengelolaan dan pengaturan pemanfaatannya. Ecowisata perairan sebagai bentuk pengelolaan berkelanjutan, merupakan salah satu aktifitas yang mengkombinasikan aspek ekologi dan ekonomi. Berangkat dari hal tersebut, pengembangan ekowisata perairan di Teluk Weda memerlukan estimasi kesesuaian kawasan. Mengacu pada Yulianda et. al (2010) analisa lesesuaian untuk ekowisata perairan dilakukan. Hasil kajian menunjukkan kawasan Teluk Weda memiliki kesesuaian sebagai berikut : ekowisata selam seluas 488,8427 Ha; ekowisata snorkeling seluas 551,3737 Ha; ekowisata pantai seluas 151,1329 Ha; ekowisata mangrove seluas 620,1251 Ha;dan ekowisata lamun seluas 32,1399 Ha.
\end{abstract}

Kata kunci : Teluk Weda, zonasi, kesesuaian kawasan, ekowisata perairan

\begin{abstract}
Weda Bay is a bay area which several resources likes renewable resources and unrenewable resources. This condition makes to develop Weda Bay as potential area, need zonation to arrange and make sustainable development. Water ecotourism as sustainable development is one of activity which can combine ecology and economic aspect. Based on this fact to development water ecotourism in Weda Bay, need to estimating suitablity area. Referring to Yulianda et. al (2010), suitabilty analysis for water ecotourism has done.Result showed Weda bay has suitable area for diving tourism as $488,8427 \mathrm{Ha}$; snorkeling tourism as $551,3737 \mathrm{Ha}$; beach tourism as 151,1329 Ha; mangrove tourism as 620,1251 Ha and seaweed tourism as 32,1399 $\mathrm{Ha}$.
\end{abstract}

Keyword: Weda Bay, zonation, suitable area, water ecotourism.

\section{Pendahuluan}

Teluk Weda yang merupakan kawasan teluk yang luas dengan kondisi sumberdaya alam yang sangat prospektif baik sebagai sumberdaya alam dapat pulih (mangrove, terumbu karang, lamun dan sumberdaya ikan), sumberdaya alam yang tak dapat pulih

\footnotetext{
${ }^{1}$ Fakultas Perikanan dan Ilmu Kelautan, Universitas Khairun

${ }^{2}$ Departemen Sumberdaya Perairan, Fakultas Perikanan dan Ilmu Kelautan, IPB
} 
(mineral dan bahan tambang) yang sangat potensial untuk dikembangkan dan sebagai pintu gerbang dan penghubung kabupaten-kabupaten di dalam dan di luar Maluku Utara.

Terkait dengan pembangunan pesisir dan pulau-pulau kecil melalui UU No. 27 Tahun 2007 tentang pengelolaan pesisir dan pulau-pulau kecil,pemerintah telah mengatur bahwa pemanfaatan pulau-pulau kecil dan perairan di sekitarnya dilakukan berdasarkan kesatuan ekologis dan ekonomi secara menyeluruh dan terpadu dengan pulau besar di dekatnya serta diprioritaskan untuk salah satu atau lebih kepentingan : konservasi; pendidikan dan pelatihan; penelitian dan pengembangan; budidaya laut; pariwisata; usaha perikanan dan kelautan dan industri perikanan secara lestari; pertanian organik, dan/atau; peternakan. Lebih lanjut, dalam Rencana Tata Ruang Wilayah yang telah ditetapkan oleh Pemerintah Daerah Kabupaten Halmahera Tengah berdasarkan Perda Nomor 1 Tahun 2012 tentang Rencana Tata Ruang Wilayah Kabupaten Halmahera Tengah Tahun 2012-2032. Hal ini diperlukan untuk menciptakan sinkronisasi antara penataan laut dengan penataan daratnya, sebagai satu kesatuan wilayah yang terpadu.

Penataan ruang (zonasi) merupakan suatu proses pengaturan yang membagi suatu wilayah secara geografis ke dalam subwilayah, dimana setiap subwilayah dirancang untuk suatu penggunaan khusus(Kay and Alder 2005). Salah satu bentuk pemanfaatan yang perlu dilakukan penataan di Teluk Weda melalui ekowisata perairan. Berangkat dari hal tersebut penata kelolaan laut, pesisir dan pulau-pulau kecil di Teluk Weda bagi perencanaan ekowisata perairan perlu dilakukan dengan mengkaji beberapa aspek, meliputi aspek ekologi (biofisik), sosial ekonomi, budaya dan kebijakan. Harapannya perencanaan ekowisata perairan yang dilakukan di Teluk Weda akan mampu mengakomodasi tujuan perlindungan bagi segenap ekosistem yang ada, bermanfaat dan berkelanjutan.

\section{Tujuan}

Penelitian ini bertujuan menyusun kesesuaian kawasan untuk pengembangan ekowisata perairan di Teluk Weda, Maluku Utara

\section{Metode}

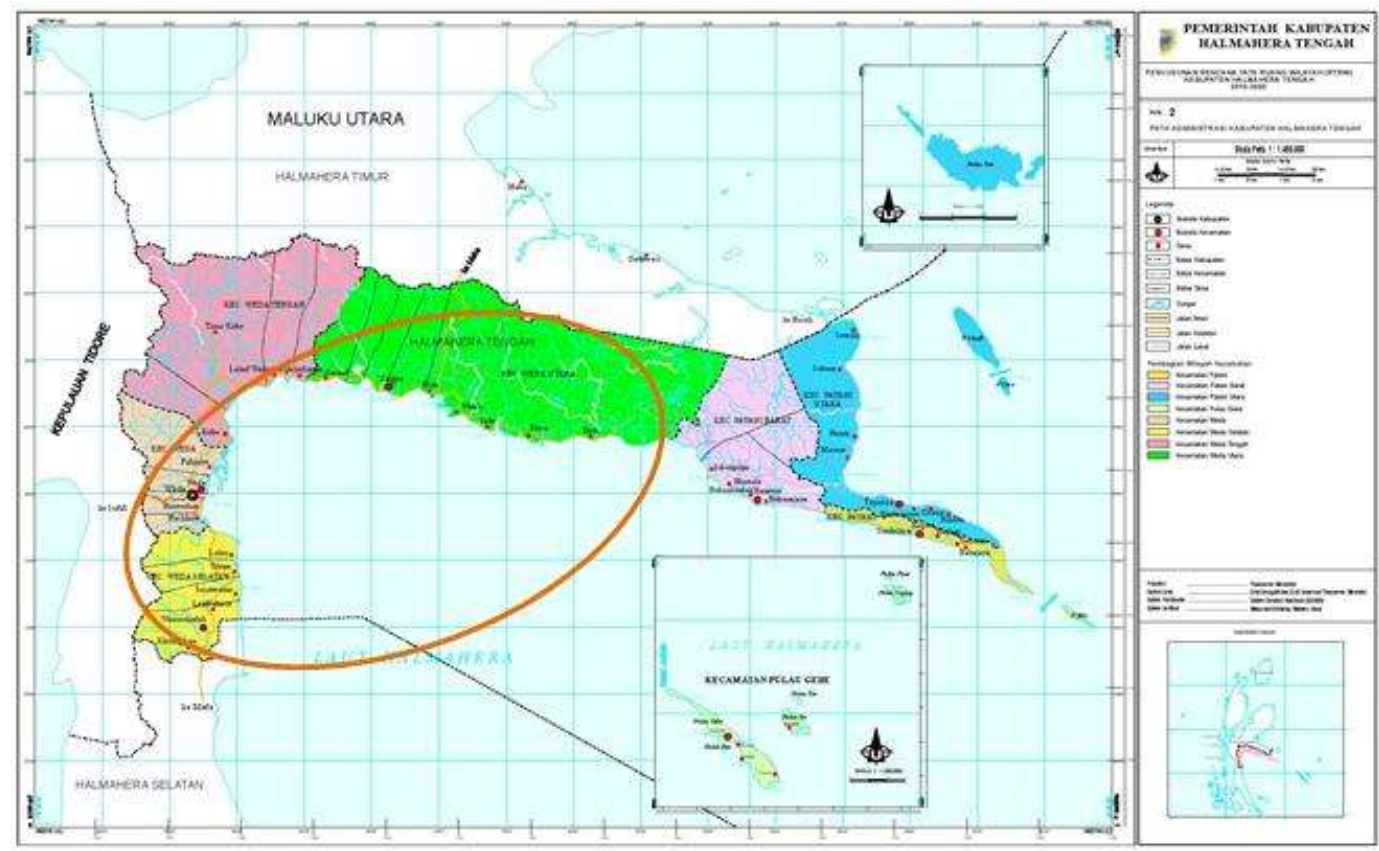

Gambar 1 Lokasi Penelitian 


\section{Lokasi Penelitian}

Penelitian dilakukan di Teluk Weda, Maluku Utara. Pelaksaaan penelitian dilakukan dengan pengumpulan data sekunder berupa data yang dikumpulkan dari Bakosurtanal, Dishidros TNI-AL, Bappeda, Balitbangda, BPS dan instansi terkait. Data primer dalam bentuk ground-check, penggunaan kuesioner serta wawancara dengan stakeholders. Peta lokasi penelitian dapat dilihat pada Gambar 1.

\section{MetodeAnalisis}

\section{Deliniasi Kondisi Eksisting}

Deleniasi kondisi eksisting pesisir dan pulau-pulau kecil di Teluk Weda dilakukan pada mangrove, lamun dan terumbu karang, tergantung pada kawasan mana yang akan dikelola berdasarkan kriteria penetapan zonasi. Penetapan zonasi mengacu pada UndangUndang Kelautan dan Perikanan Republik Indonesia Nomor 27 Tahun 2007 dan Keputusan Menteri Kelautan dan Perikanan Republik Indonesia Nomor 17 Tahun 2008 dengan kriteria penunjukkan/penetapan kawasan berdasarkan karakteristik kawasan.

\section{Analisis Spasial}

Analisis spasial dilakukan terhadap kesesuaian lahan untuk kawasan konservasi laut, dan kesesuaian lahan untuk ekowisata perairanBasis data dibentuk dari data spasial dan data atribut. Menggunakan metode tumpang susun (overlay) terhadap parameter yang berbentuk poligon. Proses overlay dilakukan dengan cara menggabungkan (union) masingmasing layers untuk tiap jenis kesesuaian lahan. Penilaian terhadap kelas kesesuaian dilakukan dengan melihat nilai Indeks Overlay dari masing-masing jenis kesesuaian lahan tersebut. Pengolahan data SIG dilakukan dengan menggunakan ArcGIS Version 10.

\section{Analisis Kesesuaian Kawasan}

Secara umum terdapat empat tahapan analisis yang dilakukan, yaitu (1) penyusunan peta kawasan, (2) penyusunan matriks kesesuaian setiap kegiatan yang akan dilakukan, (3) pembobotan dan pengharkatan, dan (4) melakukan analisis spasial untuk mengetahui kesesuaian dari setiap kegiatan yang akan dilakukan.

.Matriks kesesuaian lahan yang diperuntukkan sebagai kawasan ekowisata perairandapat dilakukan dengan menentukan kesesuaian lahan untuk ekowisata selam (diving), ekowisata berenang (snorkeling), ekowisata pantai, ekowisata mangrove, ekowisata lamun. Basis data dibentuk dari data spasial dan data atribut, selanjutnya dibuat dalam bentuk layers atau coverageyang menghasilkan peta-peta tematik dalam format digital sesuai parameter untuk masing-masing jenis kesesuaian ekowisata perairan. Algoritma yang digunakan untuk penilaian nilai indeks masing-masing jenis ekowisata perairansebagai berikut :

○ Wisata selam : ("jenis ikan karang" * 0.21) + ("kecerahan perairan" * 0.21) + ("tutupan komunitas karang" * 0.13) + ("jenis life-form" * 0.13) + ("suhu perairan" * $0.10)+($ "salinitas" * 0.13) + ("kedalaman karang" * 0.04) + ("kecepatan arus" * 0.04)

○ Wisata snorkeling : ("tutupan karang hidup" * 0.24) + ("jenis life-form" * 0.24) + ("kecerahan perairan" * 0.14) + ("jenis ikan karang" * 0.14) + ("kecepatan arus" * 0.14) + ("kedalaman karang" * 0.05) + ("lebar hamparan datar karang" * 0.05)

○ Wisata pantai : ("tipe pantai" * 0.16) + ("lebar pantai" * 0.16) + ("kedalaman perairan" * $0.16)+($ "material dasar perairan" * 0.10) + ("kecepatan arus" * 0.10) + 
("kemiringan pantai" * 0.10) + ("kecerahan perairan" * 0.05) + ("pasang surut" * 0.08) + ("penutupan lahan pantai" * 0.03) + ("biota berbahaya" * $0.05)+(" k e t e r s e d i a a n$ air tawar" * 0.03$)$

○ Wisata mangrove : ("ketebalan" * 0.28) + ("kerapatan" * 0.28) + ("jenis mangrove" * $0.17)+($ "jenis biota" * 0.17) + ("tinggi pasut" * 0.06) + ("jarak kawasan lainnya" * 0.06)

○ Wisata lamun : ("ketebalan lamun" * 0.29) + ("kecerahan perairan" * 0.18) + ("jenis ikan" * 0.18) + ("jenis lamun" * 0.18) + ("jenis substrat" * 0.06) + ("kecepatan arus" * 0.06) + ("kedalaman lamun" *0.06)

Tingkatan kesesuaian memiliki kisaran nilai indeks tertentu. Nilai indeks kesesuaian ekowisata perairandihitung berdasarkan persamaan yang dikemukan Yulianda et al. 2010 disajikan berikut ini :

Dimana :

$$
I K W=\sum\left[\frac{N_{i}}{N_{\text {maks }}}\right] \times 100 \%
$$

$I K W \quad=$ indeks kesesuaian ekominawisata

$\mathrm{Ni} \quad=$ nilai parameter ke-I (bobot $\mathrm{x}$ skor)

Nmaks = nilai maksimum dari suatu kategori ekowisata perairan

Hasil analisis kesesuaian untuk tiap jenis ekowisata perairan yang akan dikembangkan menghasilkan luasan setiap kelas kesesuaian.

\section{Hasil Dan Pembahasan}

Perencanaan pengembangan kawasan diperlukan dalam meningkatkan pengelolaan sumberdaya yang berkelanjutan di kawasan Teluk Weda, meliputi ekosistem pulau-pulau kecil, ekosistem mangrove, ekosistem lamun, ekosistem terumbu karang dan ekosistem estuaria.

Hasil deliniasi di kawasan Teluk Weda maka dapat ditentukan zonasi kawasan berdasarkan kriteria yang digunakan. Luas zonasi kawasan di Teluk Weda terbagi dalam empat kawasan yaitu, kawasan Weda Selatan, Weda, Weda Tengah dan Weda Utara dengan luas kawasan sebesar 13680,2189 Ha sebagai kawasan konservasi, kawasan perairan umum sebesar 30508,7298 Ha. Zonasi yang dihasilkan berupa zona inti, zona penyangga (pemanfaatan terbatas) dan zona pemanfaatan (pemanfaatan langsung). Peta hasil zonasi kawasan konservasi disajikan pada Gambar 2.

Lebih lanjut, pada zona pemanfaatan, kegiatan pemanfaatan yang dilakukan berupa kegiatan ekowisataperairan (selam, snorkeling, pantai, mangrove dan lamun) sehinggadapat meningkatkan nilai ekonomi bagi masyarakat yang berada di Teluk Weda.

\section{Kesesuaian Pemanfaatan Ekowisata Selam}

Sumberdaya pesisir dan pulau-pulau kecil yang sangat berpotensi untuk dikembangkan sebagai ekowisata selam yaitu adanya obyek wisata berupa ekosistem terumbu karang. Terumbu karang yang terdapat di Teluk Weda memiliki keberagaman mulai dari kedalaman 3 meter sampai 10 meter. Tiap titik kedalaman memiliki ciri khas tertentu yang merupakan suatu tantangan tersediri bagi penyelam. Terumbu karang juga dibatasi oleh kedalaman. Terumbu karang tidak dapat berkembang di perairan yang lebih dari dalam dari 50-70 meter. Kebanyakan terumbu karang tumbuh pada kedalaman 25 meter atau kurang (Nybakken 1988).

Secara visual, perairan Teluk Weda merupakan perairan yang dipenuhi hamparan gugusan karang dan gugusan karang berpasir. Kondisi ini menyebabkan untuk keluar dan 
masuk ke Kota Weda dari arah laut memerlukan kewaspadaan untuk mengikuti alur antara pulau maupun antar gugusan karang sehingga armada laut yang digunakan tidak kandas di gugusan karang dan atau pada gugusan karang berpasir. Hasil olahan citra Landsat 7ETM untuk wilayah Teluk Weda diperoleh jumlah gugusan karang sebanyak 85 gugus dengan luas keseluruhan 1773,41 Ha, sedangkan jumlah gugusan karang berpasir sebanyak 18 gugus dengan luas keseluruhan 418,05 $\mathrm{Ha}$

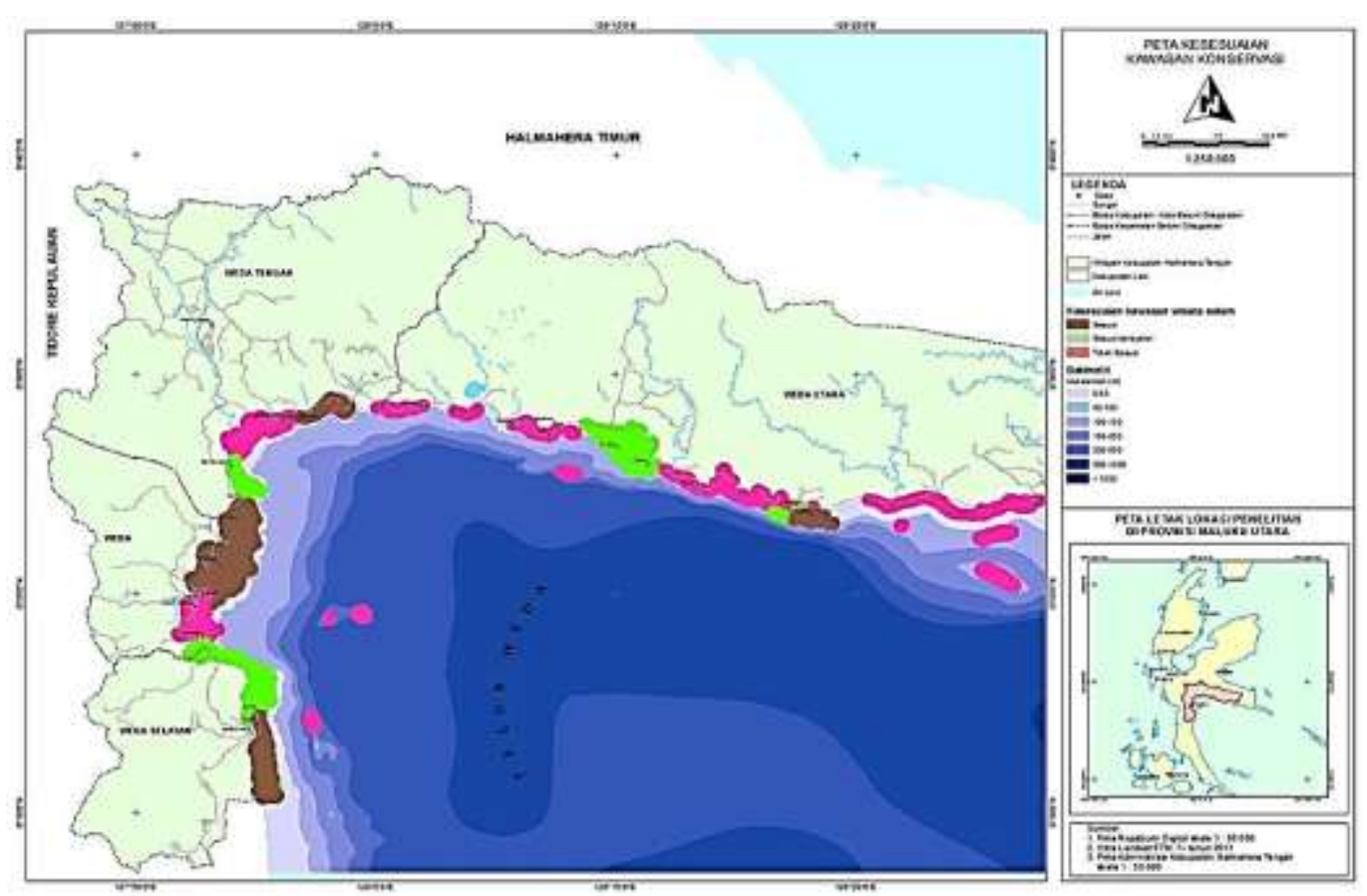

\section{Gambar 2 Zonasi kawasan di Teluk Weda}

Hasil perhitungan persen penutupan karang hidup di kedalaman $3-10 \mathrm{~m}$ menunjukkan kondisi terumbu karang di semua lokasi penyelaman berada dalam katagori rusak/kritis. Hal tersebut akibat jumlah persentase katagori tutupan hard coral $<25 \%$ dengan nilai kisaran penutupan karang sebesar 0,12 - 17,39 \% (rata-rata 7,22\%). Kondisi yang diperlihatkan tersebut menggambarkan bahwa pada saat pengamatan persentase karang hidup lebih sedikit. Dengan memperhatikan nilai persentase komponen hard coral dan komponen non hard coral dengan persentase penutupan berkisar $4-57 \%$ (rata-rata $27,10 \%$ ) maka secara kumulatif persentase penutupan karang di Teluk Weda berada masih dalam katagori layak untuk mel;akukan penyelaman sesuai DKP 2004) yang menyatakan bahwa penutupan karang $23 \%$ masih layak untuk untuk melakukan kegiatan penyelaman. Hasil analisis kesesuaian untuk pemanfaatan ekowisata selam disajikan pada Tabel 1.

Berdasarkan hasil analisis kesesuaian pemanfaatan kawasan ekowisata selam di Teluk Weda menunjukkan luasan yang sesuai (S) adalah $3.142 .327 \mathrm{~m}^{2}(314,2327 \mathrm{Ha})$, sesuai bersyarat (SB) adalah $1.746 .100 \mathrm{~m}^{2}(174.6100 \mathrm{Ha})$ dan tidak sesuai (TS) adalah 2.137.127 $\mathrm{m}^{2}(213.7127 \mathrm{Ha})$. dari total luas kesesuaian kawasan ekowisata selam. 
Tabel 1 Kesesuaian pemanfaatan kawasan ekowisata selam di Teluk Weda

\begin{tabular}{|c|c|c|c|}
\hline \multirow[b]{2}{*}{ Kawasan } & \multicolumn{3}{|c|}{ Luasan Kesesuaian $\left(\mathrm{m}^{2}\right)$} \\
\hline & Sesuai (S) & $\begin{array}{l}\text { Sesuai Bersyarat } \\
\text { (SB) }\end{array}$ & $\begin{array}{l}\text { Tidak Sesuai } \\
\text { (TS) }\end{array}$ \\
\hline Weda Selatan & 937.275 & 1.014 .537 & 555.072 \\
\hline Weda & 1.866 .265 & 381.029 & 1.198 .403 \\
\hline Weda Tengah & 146.987 & 0 & 308.925 \\
\hline Weda Utara & 191.800 & 350.534 & 74.727 \\
\hline Total & 3.142 .327 & 1.746 .100 & 2.137 .127 \\
\hline
\end{tabular}

Sumber : Hasil Analisa, 2013

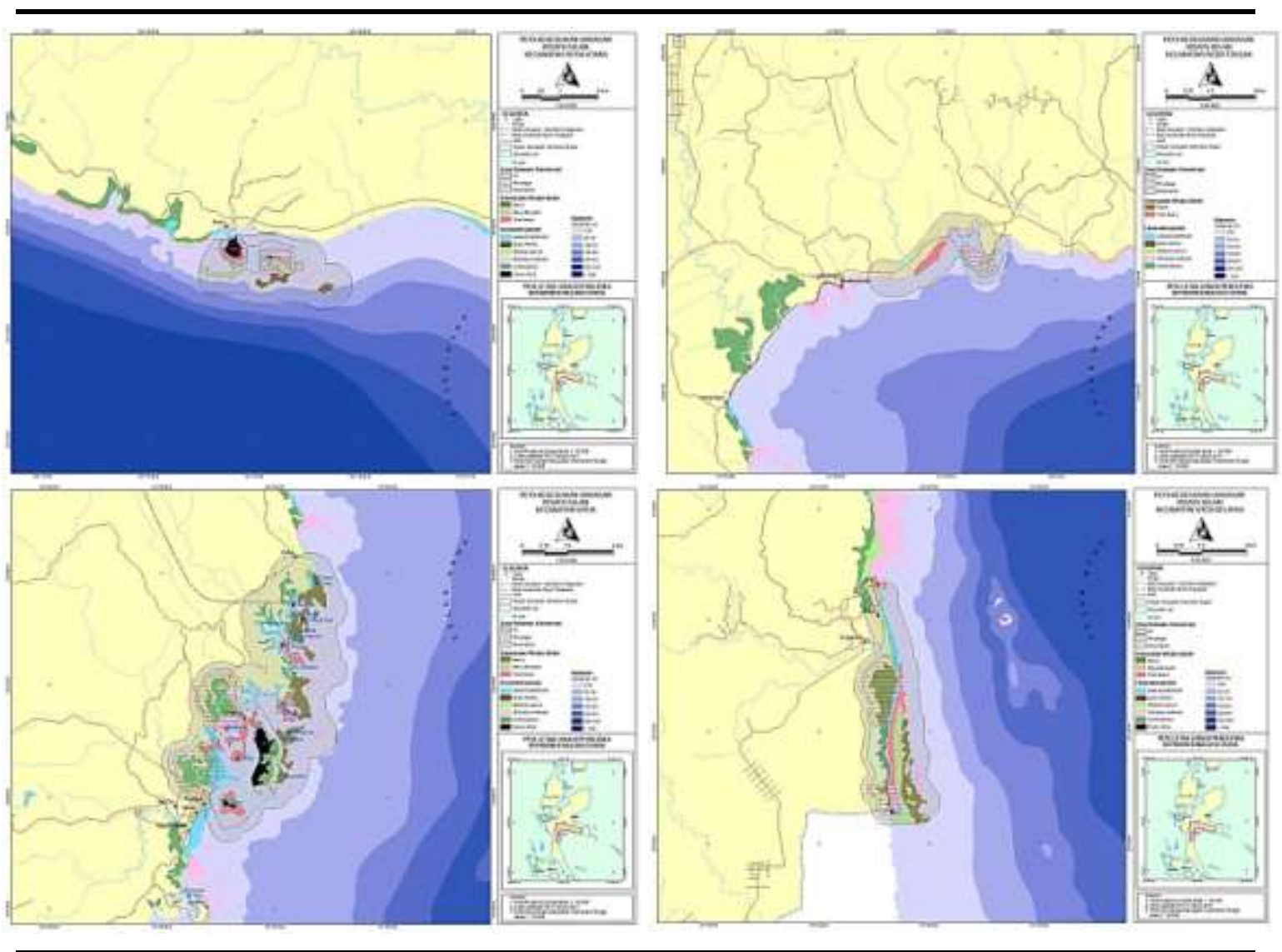

Gambar 3 Kesesuaian pemanfaatan ekowisata selam di Teluk Weda

\section{Kesesuaian Pemanfaatan Ekowisata Snorkeling}

Sama halnya dengan ekowisata selam, salah satu ekowisata yang menjadikan terumbu karang serta faktor fisik perairan sebagai obyek wisata yaitu ekowisata snorkeling atau skin diving. Ekowisata snorkeling merupakan salah satu jenis aktifitas yang dikenal dengan wisata minat khusus. Snorkeling merupakan kegiatan menikmati keindahan bawah laut yang mungkin dapat dilakukan oleh hampir semua orang. Kegiatan snorkeling hanya dapat menikmati panorama bawah laut dari lapisan permukaan air saja. Selain keberadaan terumbu karang, parameter yang turut menentukan kesesuaian ekowisata snorkling antara lain: kecerahan perairan, jenis ikan karang, kecepatan arus, kedalaman karang dan lebar hamparan datar karang. 
Luas hamparan datar karang yang teranalisis pada Citra Landsat 7 ETM diperoleh 85 gugusan karang menyebar di perairan Teluk Weda. Lebih lanjut, dari luasan tersebut selanjutnya dengan pendekatan persamaan lingkaran diperoleh diameter atau lebar hamparan datar karang. Nilai lebar hamparan ini diartikan sebagai nilai lebar rata-rata dari sisi manapun dari bentuk hamparan karang yang tidak beraturan. Lebih lanjut dari tahapan konversi yang dilakukan diperoleh panjang hamparan karang maksimum dan minimum serta-ratanya masing -masing sepanjang 1955,85 m, 53,63 m dan 383,34 m. Lebar hamparan karang $<100 \mathrm{~m}$ dijumpai pada 5 gugusan karang $(4,7 \%)$, untuk panjang hamparan 100 - $500 \mathrm{~m}$ terbentuk pada 59 gugusan karang $(69,4 \%)$ dan sisanya 22 gugusan karang merupakan gugusan karang dengan lebar hamparan > $500 \mathrm{~m}(25,9 \%)$.

Hasil analisis kesesuaian untuk pemanfaatan ekowisata snorkling dengan kriteria tutupan karang hidup, jenis life-form, kecerahan perairan, jenis ikan karang, kecepatan arus, kedalaman karang dan lebar hamparan datar karang disajikan pada Tabel 2.

Tabel 2. Kesesuaian pemanfaatan ekowisata snorkeling di Teluk Weda

\begin{tabular}{lrrr}
\hline \multirow{2}{*}{ Kawasan } & \multicolumn{3}{c}{ Luasan Kesesuaian $\left(\mathrm{m}^{2}\right)$} \\
\cline { 2 - 4 } & Sesuai (S) & $\begin{array}{c}\text { Sesuai Bersyarat } \\
(\mathrm{SB})\end{array}$ & $\begin{array}{c}\text { Tidak Sesuai } \\
(\mathrm{TS})\end{array}$ \\
\hline Weda Selatan & 1.014 .537 & 937.275 & 555.072 \\
Weda & 2.287 .741 & 285.938 & 872.018 \\
Weda Tengah & 403.595 & 52.318 & 0 \\
Weda Utara & 382.879 & 149.454 & 74.727 \\
Total & 4.088 .752 & 1.424 .985 & 1.501 .817 \\
\hline
\end{tabular}

Sumber : Hasil Analisa, 2013
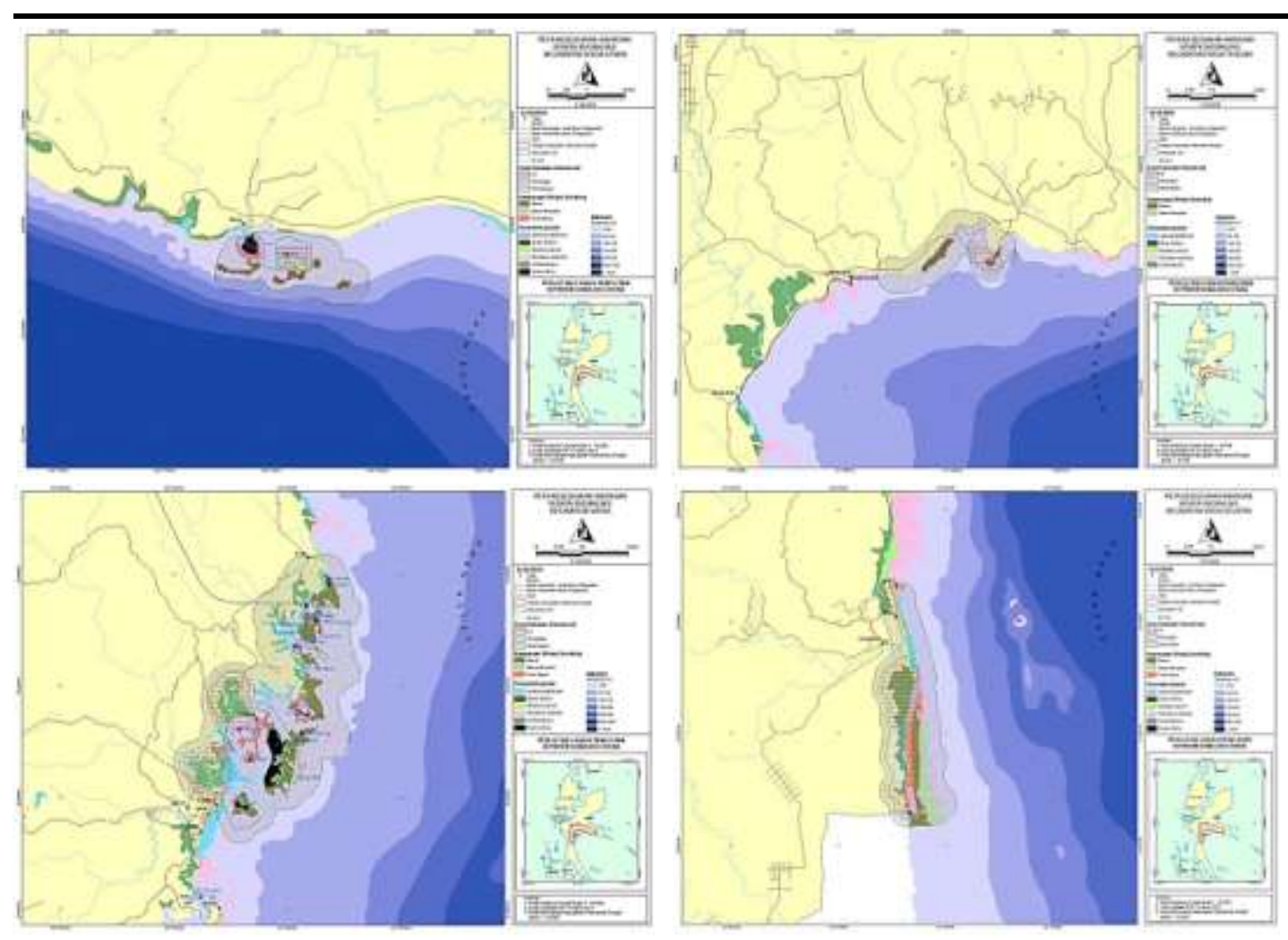

Gambar 4 Kesesuaian Pemanfaatan Ekowisata Snorkeling di Teluk Weda 
Berdasarkan hasil analisis kesesuaian pemanfaatan kawasan ekowisata snorkeling di Teluk Weda menunjukkan luasan yang sesuai (S) adalah $1.014 .537 \mathrm{~m}^{2}(101,4537 \mathrm{Ha})$, sesuai bersyarat (SB) adalah $1.424 .985 \mathrm{~m}^{2}(142,4985 \mathrm{Ha})$ dan tidak sesuai (TS) adalah $1.501 .817 \mathrm{~m}^{2}$ $(150,1817 \mathrm{Ha})$. dari total luas kesesuaian kawasan ekowisata snorkling.

\section{Kesesuaian Pemanfaatan Ekowisata Pantai}

Ekowisata pantai adalah tempat wisata yang banyak diminati oleh wisatawan lokal maupun manca negara. Pengembangan obyek wisata pantai yang mengacu pada ekowisata, pada dasarnya wisatawan diajak untuk menikmati keindahan alam sembari melakukan tindakan konservasi terhadap ekosistem di sekitar obyek wisata. Ekowisata pantai akan memberikan wisatawan berbagaipilihan atraksi wisata.Ekowisata pantai akanmenambah wawasan wisatawan karena pembelajaran terhadap alam juga menjadi atraksi tersendiri dan juga memberikanpilihanlebih dengan atraksi wisata lain bagi wisatawan.Ekowisata membutuhkan peran aktif dari wisatawan itu sendiri, semakin banyak atraksi wisata dalam sebuah obyek wisata akan berdampak pada semakin menariknya suatu daerah pariwisata.

Pantai yang banyak diminati adalah pantai yang landaian dan berpasir putih/hitam yang halus karena dibutuhkan untuk kegiatan berjemur, santai dan berenang dan juga untuk atraksi budaya. Parameter kesesuaian pemanfaatan ekowisata pantai adalah tipe pantai, lebar pantai, kedalaman perairan, material dasar perairan, kecepatan arus, kemiringan pantai, kecerahan perairan, pasang surut, penutupan lahan pantai, biota berbahaya dan ketersediaan air tawar.

Jumlah spot-spot hamparan pantai berpasir di Teluk Weda sebanyak 13 tempat dengan luas keseluruhan 21,51 Ha, sedangkan hamparan karang pasir sebanyak 18 spot dengan luas total $65.33 \mathrm{Ha}$. Pada lokasi dijumpai pantai berpasir umumnya mempunyai tipe pantai agak landai dengan jarak kedalaman 50 m berada $>600 \mathrm{~m}$ dari garis pantai (slope $4^{\circ}-7^{\circ}$ sebelum tubir) baik di bagian utara maupun selatan Teluk Weda. Dari kriteria kesesuai ekowisata pantai untuk parameter tipe pantai oleh Wong (1991), Daby (2003) dan Hutabarat et al. (2009) menunjukkan bahwa tipe pantai berpasir di Teluk Weda dalam katagori sesuai dengan tipe pantai agak landai..

Slope pantai berpasir berkisar 4o- 7osebelum tubir dan tunggang pasang surut 1,9 m memberikan penambahan lebar pantai berkisar $2-3 \mathrm{~m}$ oleh pengaruh pergerakan pasang surut sekaligus memberi katagori kesesuaian pasang surut dalam katagori tidak sesuai akibat tunggang air > 0,5 $\mathrm{m}$ (Yulianda et al. 2010). pada bagian lain pemanfaatan pantai berpasir oleh masyarakat yang menjadikannya sebagai lokasi tambat labuh perahu, penjemuran ikan serta lapangan olah raga memberikan gambaran bahwa lebar pantai berpasir di Teluk Weda dalam katagori sesuai menurut kriteria Wong (1991) dan Hutabarat et al. (2009). Kesesuaian lebar pantai tersebut akibat lebat pantai berpasir di Teluk Weda < $5 \mathrm{~m}$. Variasi slope pantai berpasir terhadap perubahan kedalaman akibat pasang surut dengan tunggang air 1,9 m memberi penambahan kedalaman perairan pantai $<2 \mathrm{~m}$ sehingga parameter kesesuaian kedalaman perairan pantai dalam katagori sesuai bersyarat (kedalaman perairan $<2-5 \mathrm{~m}$ ).menurut kriteria Wong (1991) dan Hutabarat et al. (2009).

Berdasarkan kondisi tersebut maka kesesuaian material dasar perairan terhadap ekowisata pantai termasuk dalam katagori sesuai bersyarat menurut kriteria Wong (1991), Yulianda et al. (2010) dan Hutabarat et al. (2009). Kesesuaian tersebut akibat komposisi fraksi material dasar perairan didominasi oleh material pasir berkarang, kehadiran fraksi karang tersebut karena wilayah Teluk Weda merupakan teluk terbuka dan menghadap ke Laut Pasifik dan memberikan rambatan gelombang ke pantai yang cukup besar dan mengangkut material patahan karang. 
Parameter kecepatan arusdan kecerahan perairan dalam analisis kesesuai untuk ekowisata pantai merujuk pada kriteria Wong. (1991), Yulianda et al. (2010) dan Hutabarat et al. (2009) yakni katagori sesuai jika arus $<34 \mathrm{~cm} / \mathrm{dtk}$, sesuai bersyarat $34-51 \mathrm{~cm} / \mathrm{dtk}$ dan tidak sesuai jika arusnya $>51 \mathrm{~cm} / \mathrm{dtk}$. Dari data pengukuran kecepatan arus diperoleh kecepatan rata-rata $0,26 \mathrm{~m} / \mathrm{dtk}(26 \mathrm{~cm} / \mathrm{dtk})$ dan dalam katagori sesuai. Parameter kecerahan untuk ekowisata pantai dimaksudkan untuk memberikan kesan bagi wisatawan untuk dapat melihat dengan mudah obyek dasar perairan pantai. Hasil pengukuran kecerahan rata-rata perairan Teluk Weda sebesar $68 \%$ memberikan makna bahwa kriteria parameter kecerahan untuk ekowisata pantai dalam katagori sesuai $(>50 \%)$.

Lebih lanjut, penutupan lahan pantai ini maka kesesuaian parameter penutupan lahan untuk ekowisata pantai termasuk katagori sesuai. Pada bagian lain lahan pantai berpasir dan pemenuhan kebutuhan masyarakat atas air tawar diperoleh dari daerah dalam perkampungan dalam bentuk sumur gali maupun dari sumber air sungai yang jaraknya tidak terlalu jauh disekitar perkampungan. Dari parameter ketersediaan air tawar untuk ekowisata pantai dalam katagori sesuai karena sumber air tawar berjarak $<1 \mathrm{~km}$ (Wong 1991, Yulianda et al. 2010, Suprihartono 2007 dan Hutabarat et al. 2009).

Tabel 3 Kesesuaian pemanfaatan ekowisata pantai di Teluk Weda

\begin{tabular}{lrrr}
\hline \multirow{2}{*}{ Kawasan } & \multicolumn{3}{c}{ Luasan Kesesuaian $\left(\mathrm{m}^{2}\right)$} \\
\cline { 2 - 4 } & Sesuai (S) & Sesuai Bersyarat (SB) & Tidak Sesuai (TS) \\
\hline Weda Selatan & 495.801 & 251.908 & 245.626 \\
Weda & 517.994 & 0 & 1.001 .568 \\
Weda Tengah & 0 & 0 & 0 \\
Weda Utara & 0 & 497.534 & 1.001 .568 \\
Total & 1.013 .795 & 0 & \\
\hline
\end{tabular}

Sumber : Hasil Analisa, 2013

Berdasarkanhasil analisis kesesuaian pemanfaatan kawasan ekowisata pantai di Teluk Weda yang sesuai (S) adalah $1.013 .795 \mathrm{~m}^{2}(101,3795 \mathrm{Ha})$, sesuai bersyarat (SB) adalah $497.534 \mathrm{~m}^{2}(49,7534 \mathrm{Ha})$ dan tidak sesuai (TS) adalah $1.001 .568 \mathrm{~m}^{2}(100,1568 \mathrm{Ha})$ dari total luas kesesuaian kawasan ekowisata pantai.

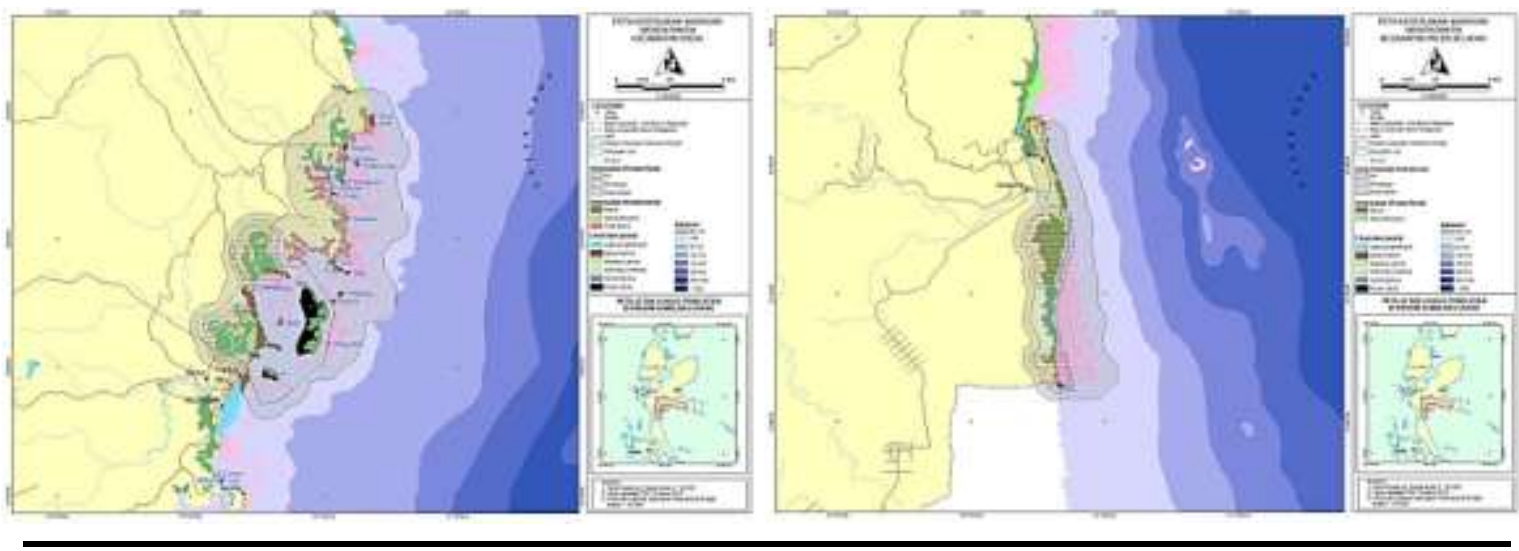

Gambar 5 Kesesuaian pemanfaatan ekowisata pantai di Teluk Weda 


\section{Kesesuaian Pemanfaatan Ekowisata Mangrove}

Ekosistem mangrove sebagai tempat rekreasi atau wisata bagi wisatawan memberikan kontribusi yang baik untuk dikembangkan, oleh karena itu diperlukan analisis kesesuaian pemanfaatan ekowisata mangrove untuk menentukan kawasan yang dapat dijadikan kawasan ekowisata mangrove, baik untuk wisata jelajah maupun wisata burung (bird waching) serta hewan-hewan yang mendiami ekosistem mangrove yang menarik bagi wisatawan.

Keberadaan ekosistem mangrove di wilayah Teluk Weda dijumpai hampir disepanjang pantai bagian tengah dari Teluk Weda dengan luas hamparan mangrove secara keseluruhan 1408,53 Ha. Jenis mangrove yang terdapat di perairan pantai Teluk Weda yakni 13 spesies dimana 7 spesies dominan berturut-turut Bruguiera gymnorizha, Sonneratia alba, Rhizophora apiculata, Rhizophora mucronata, Rhizophora stylosa, Xylocarpus granatum dan Ceriops decandra.

Terdapat enam parameter yang mendukung kesesuaian pemanfaatan ekowisata mangrove antara lain yakni ketebalan mangrove, kerapatan mangrove, jenis mangrove, jenis biota, tinggi pasut, dan jarak kawasan lainnya. Dari hasil pengukuran ketebalan mangrove dari data citra landsat 7ETM yang diukur dari daratan ke arah laut pada jarak maksimal vegetasi mangove diperoleh ketabalan minimum $11,35 \mathrm{~m}$ yang dijumpai pada mangrove di bagian selatan Teluk Weda dan ketebalan mangrove maksimum sejauh 1887,38 m yang dijumpai pada mangrove di sekitar desa Nusliku Teluk Weda bagian Utara. Dari 56 gugusan mangrove hanya 11 gugus yang mempunyai ketebalan $<100 \mathrm{~m}, 13$ gugus mempunyai ketebalan $100-200 \mathrm{~m}$ dan sisanya > $200 \mathrm{~m}$ (22 Gugus). Dari ketebalan mangrove ini sebagai parameter kesesuaian wisata mangrove berada pada kelas sesuai menurut kriteria Ayoh (2004), Hutabarat et al. (2009) dan Yaakup et al. (2006).

Hasil perhitungan kerapatan mangrove (pohon) dan jumlah jenis mangrove pada lokasi sampel diperoleh jumlah jenis mangrove tertinggi dan kerapatannya terdapat pada mangrove di Desa Goeng (Kecamatan Weda)sebanyak 7 jenis dengan kerapatan 8 ind/100 $\mathrm{m}^{2}$, disusul pada mangrove disekitar desa Sagea (Kecamatan Weda Utara)sebanyak (7 jenis) dengan kerapatan sebesar 4 ind/100 $\mathrm{m}^{2}$, Pada lokasi Tanjung Seves (Kecamatan Weda Utara)dijumpai 6 jenis mangrove dengan kerapatan 6 Ind $/ 100 \mathrm{~m}^{2}$. dan Tanjung Kife di Kecamatan Weda Utara sebanyak 6 jenis dengan kerapatan 8 Ind $/ 100 \mathrm{~m}^{2}$ dan mangrove di siktar Desa Loleo Kecamatan Weda sebanyak 6 jenis dengan kerapatan selatan 2 Ind $/ 100 \mathrm{~m}^{2}$. Pada lokasi mangrove tersebut selama pengambilan data dijumpai jenis biota lain seperti Ikan, udang, Kepiting, Molusca, reptil dan burung. Uraian parameter jumlah jenis mangrove, kerapatan mangrove dan kehadiran biota lain pada komunitas mangrove menunjukkan kelas kesesuaian yang sama yakni katagori sesuai dengan skor kesesuaian yang berbeda. Kesesuain jumlah jenis mangrove merujuk pada Yulianda et al.(2010)dan MERDI in DKP (2006a) dengan kriteria kesesuaian jumlah jenis < 3, untuk kerapatan mangrove merujuk Yulianda et al.(2010) dengan kriteria katagori sesuai kerapatan mangrove sebesar $>3-25$ ind $/ 100 \mathrm{~m}^{2}$ dan untuk kehadiran biota lain pada komunitas mangrove sesuai dengan Yulianda et al.(2010) dan MERDI in DKP (2006a) dengan kriteria ditemukan biota lain pada vegetasi mangrove seperti Ikan, udang, Kepiting, Molusca, reptil dan burung.

Parameter jarak komunitas mangrove dengan kawasan lainnyaadalah jarak minimum keberadaan mangrove dengan kawasan lainnya seperti perkampungan, lokasi penambangan, pelabuhan, pusat pemerintahan dan lain-lain. Berdasarkan hasil pemantauan saat penelitian umumnya pemukiman masyarakat berada dalam komunitas mangrove, hal yang sama juga terlihat pada aktifitas pelabuhan, dimana pelabuhan dan beberapa fasilitas umum lainnya dibangun pada kawasan mangrove dengan melakukan reklamasi. Kondisi ini menggambarkan bahwa kriteria jarak komunitas mangrove terhadap kawasan lainnya relatif dekat $(<300 \mathrm{~m})$ sehingga dikatagorikan tidak sesuai menurut 
Bengen (2000). Hasil analisis kesesuaian pemanfaatan ekowisata mangrove dari 6 parameter kriteria disajikan pada Tabel 4.

Tabel 4Kesesuaian pemanfaatan ekowisata mangrove di Teluk Weda

\begin{tabular}{lrrr}
\hline \multirow{2}{*}{ Kawasan } & \multicolumn{3}{c}{ Luasan Kesesuaian $\left(\mathrm{m}^{2}\right)$} \\
\cline { 2 - 4 } & Sesuai $(\mathrm{S})$ & \multicolumn{1}{c}{ Sesuai Bersyarat $(\mathrm{SB})$} & \multicolumn{1}{c}{ Tidak Sesuai (TS) } \\
\hline Weda Selatan & 653.044 & 1.344 .491 & 0 \\
Weda & 1.760 .834 & 2.293 .906 & 169.421 \\
Weda Tengah & 0 & 0 & 0 \\
Weda Utara & 151.946 & 0 & 0 \\
Total & 2.565 .824 & 3.638 .397 & 169.421 \\
\hline
\end{tabular}

Sumber : Hasil Analisa, 2013

Berdasarkan hasil analisis kesesuaian pemanfaatan kawasan ekowisata mangrove di Teluk Weda yang sesuai (S) adalah $2.565 .824 \mathrm{~m}^{2}(256,5824 \mathrm{Ha})$, sesuai bersyarat (SB) adalah 3.638.397 $\mathrm{m}^{2}(363,8397 \mathrm{Ha})$ dan tidak sesuai (TS) adalah $169.421 \mathrm{~m}^{2}(16,9421 \mathrm{Ha})$ dari total luas kesesuaian kawasan ekowisata mangrove.
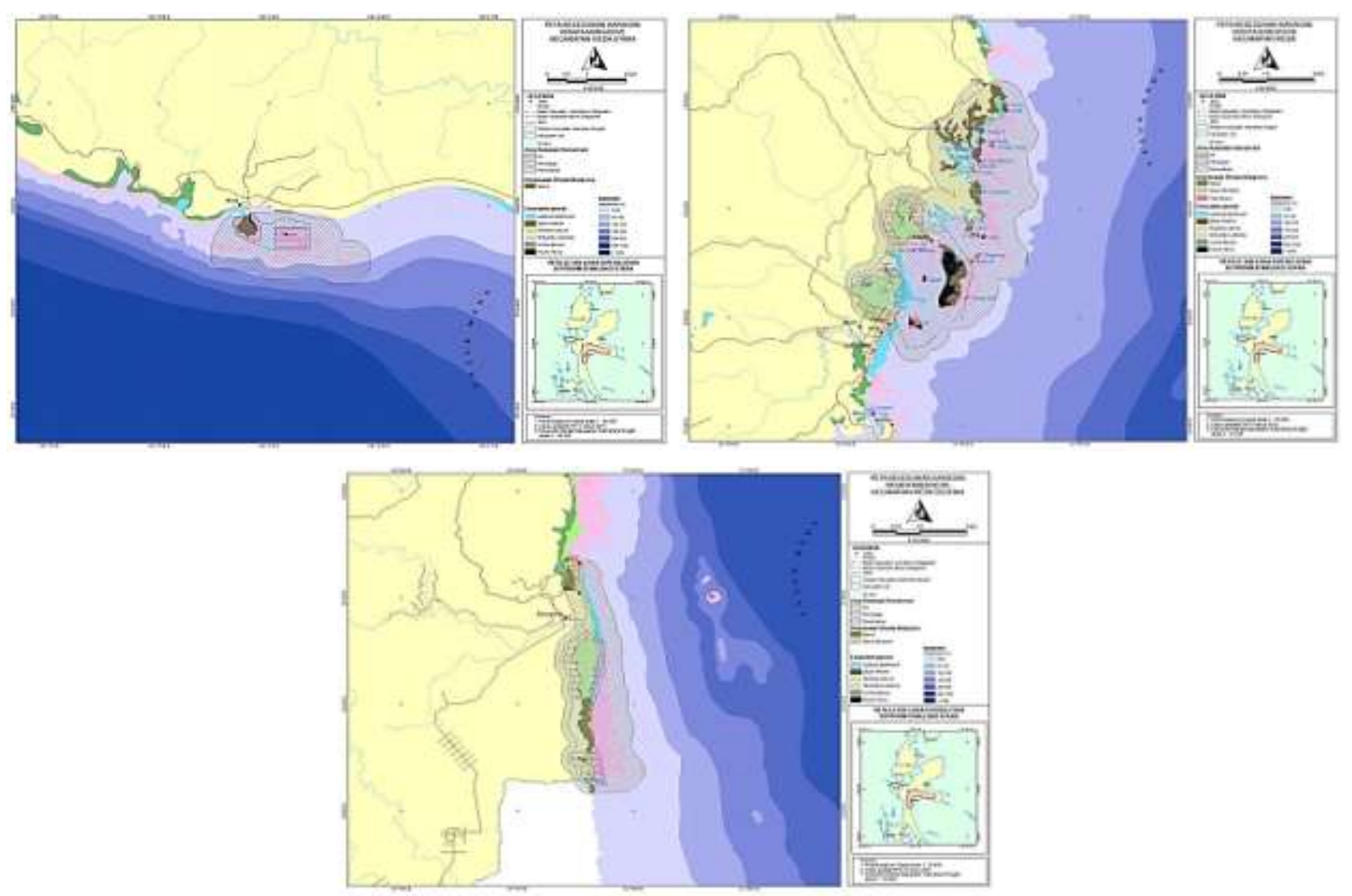

Gambar 6 Kesesuaian pemanfaatan ekowisata mangrove di Teluk Weda

\section{Kesesuaian Pemanfaatan Ekowisata Lamun}

Ekosistem lamun umumnya membentuk padang lamun yang luas didasar laut yang masih dapat dijangkau oleh cahaya matahari yang memadai bai pertumbuhannya. 
Ekosistem lamun hidup di perairan yang dangkal dan jernih pada kedalaman berkisar antara 2-12 meter, dengan sirkulasi air yang baik (Mann 2000).

Nilai ekonomi biota yang berkaitan dengan padang lamun belum banyak diketahui, namun pemanfaatan lamun secara langsung di berbagai negara sudah banyak dilakukan. Di beberapa negara, lamun digunakan untuk menggantikan makanan bagi hewan dan komponen pupuk di daerah pesisir, sebagai bahan baku pembuatan kertas dan bahan pengganti dalam pabrik nitro selulosa, serta bahan pencegah kebakaran (Puspitaningasih 2012). Selain manfaat yang telah disebutkan, salah satu pemanfaatan lamun adalah sebagai tempat untuk rekreasi atau ekowisata pada padang lamun.

Luas hamparan lamun dari hasil analisis citra landsat 7ETM diperoleh luas hamparan komunitas lamun sebesar 111,11 Ha yang dominan tersebar dibagian utara dan tengah Teluk Weda dalam 18 gugusan padang lamun. Hasil perhitungan ketebalan padang lamun berdasarkan luas gugusan padang lamun diperoleh ketebalan minimum dan maksimum sepanjang 41,41 m dan 371,96 m. Dari ketebalan padang lamun tersebut terhadap kriteria kesesuaian berada dalam katagori sesuai bersyarat dan sesuai menurut Yulianda et al. (2010)., jika dengan mempertimbangkan jumlah gugusan lamun dengan ketebalan lamun dalam katagori sesuai bersyarat lebih sedikit (42\%) sehingga secara umum kriteria kesesuain ketebalan padang lamun untuk wisata lamun dalam katagori sesuai.

Parameter kecerahan perairan untuk wisata lamun dimaksudkan sebagai parameter dalam kajian prospek keberlanjutan sumberdaya pada komunitas lamun. Kecerahan merupakan penetrasi cahaya yang masuk ke dalam perairan yang digunakan untuk proses fotosintesis padang lamun. Kecerahan juga sebagai indikasi adanya masukan material tersuspensi yang menyebabkan kekeruhan sehingga menghambat proses fotosintesis. Hal ini secara luas akan mengganggu produktifitas primer padang lamun. Hasil pengukuran kecerahan perairan diperoleh rata-rata sebesar $68 \%$, dengan nilai kecerahan tersebut maka katagori kesesuaian menurut Yulianda et al. (2010) untuk kegiatan wisata lamun berada dalam katagori sesui bersyarat.

Hasil wawancara dengan masyarakat dan nelayan di lokasi penelitian tentang jenis ikan yang sering mereka temukan di padang lamun melalui media gambar teridentifikasi 7 jenis ikan. Ikan-ikan tersebut yakni ikan Kakatua(Scarus spp), Ikan Uhi garis-garis (Siganusjavus),Ikan uhi abu-abu(Siganus spinus), Ikan Gutila (Lethrinus lentjan), Ikan Gorara (Lethrinus spp)Ikan gudida(Lutjanus johnil), dan Ikan pagar-pagar(Abudefduf spp). Dari jumlah jenis ikan yang menjadikan padang lamun sebagai habitatnya tersebut menunjukkan bahwa kriteria kesesuaian wisata lamun dengan para meter jumlah jenis ikan berada dalam katagori kesesuaian bersyarat (Yulianda et al. 2010) dengan jumlah spesies ikan padang yang teridentifikasi sebanyak 6 - 10 spesies.

Jenis lamun yang ditemukan pada perairan Teluk Weda sebanyak 10 jenis yakni Enhalus acoroides, Halophila ovalis, Cymodocea rotundata, Thalassia hemprichii, Halodule uninervis, Halophila decipiens, Halodule pinifolia, Halodule minor, Cymodocea serrulata dan Syringodium isotifolium. Jenis lamun Enhalus acoroides dan Thalassia hemprichii merupakan jenis lamun yang selalu dijumpai pada setiap lokasi. Dengan ditemukannya kedua jenis tersebut menggambarkan parameter jenis lamun dalam katagori tidak sesuai untuk kesesuaian wisata lamun (Yulianda et al. 2010).Lebih lanjut, jenis lamun tersebut menyebar pada kedalaman 3 meter dan substrat dasar perairan dari material pasir berkarang, sehingga kesesuaian parameter kedalaman lamun dan jenis substrat untuk wisata selam dalam katagori sesuai (Yulianda et al. 2010).

Kecepatan arus yang berkembang pada padang lamun memberi kontribusi pada produktifitas padang lamun dan juga berfungsi pada transport nutrien bagi organisme sekaligus pengangkutan bahan buangan. Hasil pengukuran kecepatan arus pada padang lamun diperoleh kecepatan arus berkisar 0,09-0,15 $\mathrm{m} / \mathrm{dtk}$ atau rata-rata kecepatan arus pada padang lamun sebesar $0,12 \mathrm{~m} / \mathrm{dtk}(12 \mathrm{~cm} / \mathrm{dtk})$. Dengan kecepatan arus tersebut 
maka parameter kesesuaian kecepatan arus untuk wisata lamun termasuk dalam katagori sesuai menurut Yulianda et all, (2010) dengan nilai kesesuaian kecepatan arus berada antara $0-17 \mathrm{~cm} / \mathrm{dtk}$.

Tabel 5 Kesesuaian pemanfaatan ekowisata lamun di Teluk Weda

\begin{tabular}{lrrr}
\hline \multirow{2}{*}{ Kawasan } & \multicolumn{3}{c}{ Luasan Kesesuaian $\left(\mathrm{m}^{2}\right)$} \\
\cline { 2 - 4 } & \multicolumn{1}{c}{ Sesuai (S) } & Sesuai Bersyarat (SB) & Tidak Sesuai (TS) \\
\hline Weda Selatan & 151.979 & 39.863 & 0 \\
Weda & 129.557 & 0 & 117.098 \\
Weda Tengah & 0 & 0 & 0 \\
Weda Utara & 0 & 0 & 0 \\
Total & 281.536 & 39.863 & 117.098 \\
\hline
\end{tabular}

Sumber : Hasil Analisa, 2013

Hasil analisis kesesuaian pemanfaatan ekowisata lamun dengan parameter kesesuaian pemanfaatan ekowisata lamun terdiri dari : ketebalan lamun, kecerahan perairan, jenis ikan, jenis lamun, jenis substrat, kecepatan arus, dan kedalaman lamun disajikan pada Tabel 5.

Berdasarkanhasil analisis kesesuaian pemanfaatan kawasan ekowisata lamun di Teluk Weda yang sesuai (S) adalah $281.536 \mathrm{~m}^{2}(28,1536 \mathrm{Ha})$, sesuai bersyarat (SB) adalah $39.863 \mathrm{~m}^{2}(3,9863 \mathrm{Ha})$ dan tidak sesuai (TS) adalah $117.098 \mathrm{~m}^{2}(11,7098 \mathrm{Ha})$ dari total luas kesesuaian kawasan ekowisata lamun.

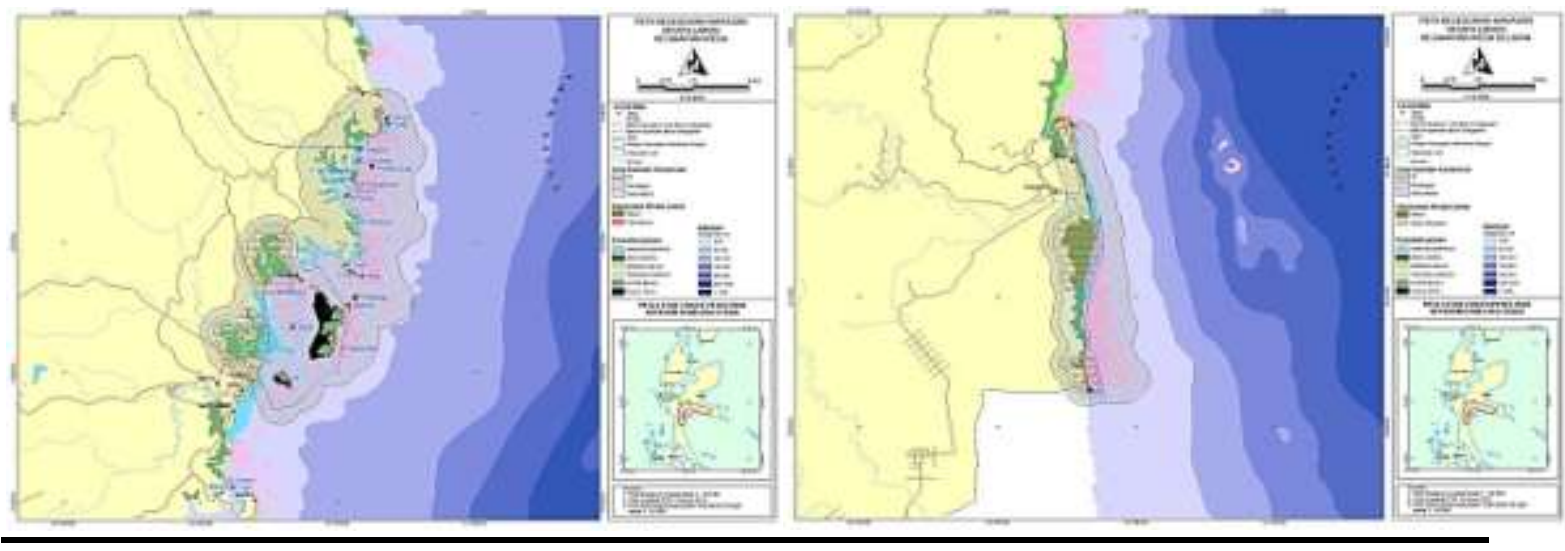

Gambar 7 Kesesuaian pemanfaatan ekowisata lamun di Teluk Weda

\section{Kesimpulan}

Berdasarkan hasil analisis dan pemetaan kesesuaian kawasan pemanfaatan untuk pengembangan ekowisata perairandi Teluk Weda, maka disimpulkan bahwa kawasan pemanfaatanmemiliki luas kawasan konservasi sebagai berikut : ekowisata selam $(488,8427$ Ha), ekowisata snorkeling (551,3737 Ha), ekowisata pantai (151,1329 Ha), ekowisata mangrove $(620,1251 \mathrm{Ha})$, ekowisata lamun $(32,1399 \mathrm{Ha})$ 


\section{Daftar Pustaka}

Bengen DG. 2002. Mengenal dan Memelihara Mangrove. Pusat Kajian Sumberdaya Pesisir dan Lautan Institut Pertanian Bogor, Bogor.

[DKP RI] Departemen Kelautan dan Perikanan Republik Indonesia. 2004. Pedoman pengembangan wisata bahari berbasis masyarakat doi kawasan konservasi laut. Dirjen Kelautan Pesisir dan Pulau-Pulau Kecil. Departemen Kelautan dan Perikanan. Jakarta

[DKP RI] Departemen Kelautan dan Perikanan Republik Indonesia. 2009. Seri Kebijakan dan Pengembangan Kawasan Konservasi Perairan. Kumpulan Peraturan Perundang-undangan di Bidang Pengelolaaan Terumbu Karang. Satker Rehabilitasi dan Pengelolaan Terumbu Karang. Direktorat Jenderal Kelautan, Pesisir dan Pulau-Pulau Kecil. Departemen Kelautan dan Perikanan.

[DPK] Dinas Perikanan dan Kelautan, Provinsi Maluku. 2006. Laporan Hasil Identifikasi Calon Kawasan Konservasi Laut Daerah (KKLD) di Provinsi Maluku.

Kay R, Alder J. 2005. Coastal planning and management. E \& FN Spon, London and New York.

Kustanti A. 2011. Manajemen Hutan Mangrove. Penerbit IPB Press. Kampus IPB Taman Kencana Bogor.

Nybakken JW. 1992. Biologi Laut. Suatu Pendekatan Ekologis. Penerbit PT Gramedia, Jakarta.

Mann KH. 2000. Ecology of Coastal Waters. With Implication for Management. Blackwell Science, Inc, Massachusetts.

[PERDA] Peraturan Daerah Kabupaten Halmahera Tengah Tahun 2012. Rencana Tata Ruang Wilayah Kabupaten Halmahera Tengah Tahun 2012-2032. Kabupaten Halmahera Tengah.

Puspitaningasih. 2012. Mengenal Ekosistem Laut dan Pesisir. Penerbit Pustaka Sains, Bogor.

Supriharyono. 2007. Konservasi Ekosistem Sumberdaya Hayati Di Wilayah Pesisir dan Laut Tropis. Pustaka Pelajar. Yogyakarta

Wong. 1998. Coastal Tourism Development in Southeast Asia: Relevance and Lessons for Coastal Zone Management. j.ocecostmanag. 38: 89-109.

Yulianda F, Fahrudin A, Hutabarat AA, Hartaeti S, Kusharjani, Kang HS. 2010. Pengelolaan Pesisir dan Laut secara Terpadu. Pusat Pendidikan dan Pelatihan Kehutanan - Departemen Kehutanan RI. SECEM Korea International Cooperation Agency. 